\title{
Spiking and non-spiking classes of oligodendrocyte precursor glia in CNS white matter
}

\author{
Ragnhildur Káradóttir ${ }^{1}$, Nicola B. Hamilton, Yamina Bakiri, and David Attwell \\ Department of Physiology, University College London, Gower Street, London, WC1E 6BT, \\ England
}

\begin{abstract}
A defining feature of glial cells has been their inability to generate action potentials. We now show that there are two distinct types of morphologically identical oligodendrocyte precursor glial cell (OPC) in situ in rat CNS white matter. One type expresses voltage-gated sodium and potassium channels, generates action potentials when depolarized, and senses its environment by receiving excitatory and inhibitory synaptic input from axons. The other type lacks action potentials and synaptic input. We show that when OPCs suffer glutamate-mediated damage, as occurs in cerebral palsy, stroke and spinal cord injury, the action potential generating OPCs are preferentially damaged because they express more glutamate receptors and in ischaemia receive increased spontaneous glutamatergic synaptic input. These data challenge the idea that only neurons generate action potentials in the CNS, and imply that the development of therapies for demyelinating disorders will require defining which OPC type can perform remyelination.
\end{abstract}

Oligodendrocyte precursor glia, which express1 the proteoglycan NG2, transform into myelinating oligodendrocytes during development2, but are also present in the adult CNS3 where they comprise $\sim 5 \%$ of the cells and are the main proliferating cell type4,5. Damage to oligodendrocyte precursors, leading to reduced myelination, contributes to mental and physical impairment in periventricular leukomalacia (pre- or perinatal white matter injury leading to cerebral palsy)6. Adult OPCs may form new myelinating oligodendrocytes in multiple sclerosis and spinal cord injury 7-12, and OPC transplants could serve as a basis for therapeutic remyelination13. However, the functions of OPCs are poorly understood: they may simply become oligodendrocytes in normal development and constitute a reservoir of cells which replace damaged myelin in the adult CNS, but they might also differentiate into other cell types and thus have some stem cell characteristics14. Understanding the diversity of NG2-expressing OPCs is crucial for understanding normal brain function, for appreciating the diversity of the brain's progenitor cell population, and for developing therapeutic strategies to treat demyelinating diseases.

\section{Results}

\section{Identification of oligodendrocyte precursor glia}

In the cerebellum of postnatal day 7 (P7) rats, cells expressing NG2 constitute $14.8 \pm 1.2 \%$ $(\mathrm{n}=1850$ cells $)$ of the cells present in the white matter (Fig. 1a). Essentially all of these cells (93 $\pm 2 \%$, excluding perivascular NG2 cells 15$)$ also labelled for the oligodendrocyte transcription factor Olig2 (Fig. 1b-d), defining them as OPCs16,17.

\footnotetext{
Send correspondence to Ragnhildur Káradóttir, Department of Veterinary Medicine, University of Cambridge, Madingley Road, Cambridge, CB3 0ES, UK. Tel: (+44)-1223-765-860; Email: rk385@ cam.ac.uk.

${ }^{1}$ Current address: Dept of Veterinary Medicine, University of Cambridge, Madingley Road, Cambridge, CB3 OES, UK. Tel: (+44)-1223-765860; Email: rk385@cam.ac.uk
} 
To investigate their electrophysiological properties, we whole-cell patch-clamped cells in cerebellar slices and identified them as oligodendrocyte precursors from post-recording dyefill morphology (exhibiting processes not well aligned with nearby axons: Fig. 1e) and antibody labelling 18,19 . NG2 antibody successfully labelled 45 out of 45 recorded cells with precursor morphology that were tested, while Olig2 antibody successfully labelled 32 out of 36 cells tested (Fig. 1e-h). In some experiments, more rapid identification of NG2expressing OPCs was attained by labelling the living slice with an antibody to an extracellular epitope of NG2, which decorated the surface of the OPCs, allowing subsequent whole-cell clamping (Fig 1i-k). For both identification methods, OPCs fell into two distinct electrophysiological classes.

\section{Two classes of oligodendrocyte precursor glia}

One class of OPCs (which we call $\mathrm{I}_{\mathrm{Na}}$ cells) exhibited a transient inward current on depolarization beyond $-50 \mathrm{mV}$ (Fig 2a), which was reversibly blocked by TTX (Fig. 2c, n=6 cells) and was inactivated by maintained depolarization to $-30 \mathrm{mV}$ (data not shown), indicating that it is mediated by voltage-gated $\mathrm{Na}^{+}$channels. The peak amplitude of the $\mathrm{Na}^{+}$ current was $\sim 1 \mathrm{nA}(1.09 \pm 0.13 \mathrm{nA}, \mathrm{n}=76)$ on depolarization from $-70 \mathrm{mV}$ to $-10 \mathrm{mV}$ (Fig. $2 \mathrm{~d}$ ). This was followed by activation of a maintained outward current when $\mathrm{K}^{+}$was the main pipette cation, which led to a decreased steady state slope resistance at depolarized potentials (Fig. 2g, i, j). When $\mathrm{Cs}^{+}$was the main pipette cation, this outward current was abolished (Fig. 2h), indicating that it is produced by voltage-gated $\mathrm{K}^{+}$channels. The other class of OPCs (no I $\mathrm{Na}_{\mathrm{Na}}$ ) exhibited an essentially time-independent I-V relation (Fig. 2b) with a resistance that was almost voltage-independent (Fig. $2 \mathrm{~g}-\mathrm{j}$ ).

Out of 232 recorded OPCs at $\mathrm{P} 7,46 \%$ showed voltage-gated $\mathrm{Na}^{+}$and $\mathrm{K}^{+}$currents. A similar divison of OPCs into $\mathrm{I}_{\mathrm{Na}}$ and no- $\mathrm{I}_{\mathrm{Na}}$ cells was obtained using pan- $\mathrm{Na}^{+}$channel antibody labelling at P12 (Fig. 2e, f): approximately half of the white matter cells expressing NG2 and Olig2 also expressed voltage-gated $\mathrm{Na}^{+}$channels, while the other half displayed no detectable $\mathrm{Na}^{+}$channel labelling. This division of OPCs into two classes expressing and lacking voltage-gated $\mathrm{Na}^{+}$channels was also observed electrophysiologically at P12 (data not shown), and was maintained in the adult animal where $\sim 70 \%$ of the cells expressed $\mathrm{Na}^{+}$ channels and 30\% did not (Fig. 2f) and 3 out of 6 recorded cells with precursor morphology showed a voltage-gated $\mathrm{Na}^{+}$current (mean amplitude at $-10 \mathrm{mV}$ was $1.07 \pm 0.20 \mathrm{nA}$, not significantly different from at $\mathrm{P} 7, P=0.97$ ) while the other 3 did not (all 4 cells that were tested for NG2 labelling expressed it). The two cell classes were separable on a scatter plot of $\mathrm{I}_{\mathrm{Na}}$ magnitude against slope resistance at depolarized potentials (Fig. 2k).

Despite this clear electrophysiological difference, the two precursor types had a similar morphology, with no significant difference in their soma size, number of processes, or the length or width of their field of processes (Fig. 21), suggesting that they do not reflect a different developmental stage. Furthermore, although at P7-P12 the OPCs were split approximately equally into classes expressing and lacking $\mathrm{Na}^{+}$channels (Fig. 2f), at P7 we found that only $17 \pm 5 \%$ of $228 \mathrm{NG} 2$ expressing cells also expressed O4, a marker of late precursors and immature oligodendrocytes 20 (significantly different from the $46 \%$ of cells expressing $\mathrm{I}_{\mathrm{Na}}(P=0.002)$ and from the $54 \%$ of cells lacking $\left.\mathrm{I}_{\mathrm{Na}}(P=0.0007)\right)$. Similarly, only $3.7 \pm 1.3 \%$ of $141 \mathrm{NG} 2$ expressing cells also expressed GalC, a marker of immature oligodendrocytes 20 (significantly different from the $46 \%$ of cells expressing $\mathrm{I}_{\mathrm{Na}}(P=$ $\left.6.6 \times 10^{-8}\right)$ and from the $54 \%$ of cells lacking $\left.\mathrm{I}_{\mathrm{Na}}\left(P=2.3 \times 10^{-8}\right)\right)$. These data exclude the possibility that the appearance or disappearance of $\mathrm{Na}^{+}$channel expression is linked developmentally to upregulation of $\mathrm{O} 4$ or $\mathrm{GalC}$. The cells lacking $\mathrm{Na}^{+}$channels are not astrocytes14,21, as they express NG2 and Olig2, and did not express S100 $\beta$ which is commonly expressed by astrocytes (at postnatal day 12, 0 of 104 NG2 and Olig2 expressing cells in fixed tissue were S100 $\beta$ positive: Fig. 3a). 
Both classes of precursor seem able to proliferate, since we recorded from cells, with or without $\mathrm{I}_{\mathrm{Na}}$, which appeared to be in the process of cell division: when one cell was wholecell clamped it showed cytoplasmic continuity allowing dye movement to one other cell with a closely apposed soma which appeared to be separating from the recorded cell (Fig. $3 \mathrm{c}, \mathrm{d} ; 2$ of $107 \mathrm{I}_{\mathrm{Na}}$ cells, and 7 of 125 no $\mathrm{I}_{\mathrm{Na}}$ cells, not significantly different, $P=0.26$ ). The remaining 223 out of 232 cells ( $96 \%$ ) showed no dye coupling. The fact that only 2 out of $107 \mathrm{I}_{\mathrm{Na}}$ cells showed Lucifer yellow passing to another cell, while 107 of 232 recorded cells expressed $\mathrm{I}_{\mathrm{Na}}$ (significantly different, $P=1.5 \times 10^{-15}$ ), proves that the presence of $\mathrm{I}_{\mathrm{Na}}$ is not an artefactual consequence of a hypothetical and previously unreported gap junctional coupling of OPCs to neurons.

\section{One class of OPC generates action potentials}

In current clamp recordings, injecting depolarizing current into OPC glia expressing voltage-gated $\mathrm{Na}^{+}$channels evoked action potentials (Fig. 4a), which were reversibly blocked by TTX (Fig. 4b). The threshold current needed to produce an action potential was approximately inversely proportional to the input resistance at the resting potential (correlation coefficient $\mathrm{r}^{2}=0.44$ ). In contrast, depolarizing cells lacking $\mathrm{Na}^{+}$channels evoked no action potentials ( $\mathrm{n}=5$, Fig. $4 \mathrm{c})$. In most $\mathrm{I}_{\mathrm{Na}}$ cells $(9 / 12)$ an increasing action potential frequency was produced by larger currents until a depolarizing block of action potentials occurred (Fig. 4a), whereas some cells (3/12) showed a single action potential with a latency that decreased with larger currents (Fig. 4d). The number of action potentials produced by an injected current of $200 \mathrm{pA}$ for $200 \mathrm{msec}$ correlated approximately $\left(\mathrm{r}^{2}=0.41\right.$, 8 cells) with the magnitude of the $\mathrm{Na}^{+}$current seen on depolarizing from $-70 \mathrm{mV}$ to $-10 \mathrm{mV}$, but not with the input resistance at the resting potential $\left(\mathrm{r}^{2}=0.02\right)$.

Although the $\mathrm{Na}^{+}$channel expressing cells resemble neurons in their ability to generate action potentials, they are not neurons since they express NG2 and Olig2, and did not express the neuronal marker NeuN even at postnatal day 12 ( 0 out of 216 NG2/Olig2 cells in fixed tissue were NeuN positive, Fig. 3b), ruling out a conversion of NG2 cells into NeuN positive neurons as suggested for grey matter NG2 cells 22,23 . In 2 out of 6 cells recorded for long periods, spontaneous action potentials were observed (Fig. 4e), implying that action potentials in these glia are not just evoked by injected current, but play a role in the normal function of the cells.

\section{Action potential generating OPCs receive synaptic input}

Some OPCs received synaptic input (Fig. 5a), which was largely blocked by TTX (although some spontaneous synaptic currents remained in the presence of TTX: Fig. 5b, c). Thus action potentials in neuronal axons can evoke transmitter release onto OPCs18,24,25. This input comprised EPSCs, presumably reflecting glutamate release from mossy or climbing fibre axons, or IPSCs, probably reflecting activity in GABAergic Purkinje cell axons, or a mixture of EPSCs and IPSCs (Fig. 5a, d). NBQX $(25 \mu \mathrm{M})$ and D-AP5 $(50 \mu \mathrm{M})$ almost abolished the inward synaptic currents (Fig. $5 \mathrm{~g}$,i) and also reduced by $60 \%$ the frequency of outward currents, presumably by reducing Purkinje cell firing, while the $\mathrm{GABA}_{\mathrm{A}}$ receptor blocker GABAzine $(10 \mu \mathrm{M})$ abolished the outward synaptic currents (Fig. 5h,j) and had no significant effect on the inward currents.

Strikingly, whereas $81 \%$ of cells expressing $\mathrm{Na}^{+}$channels exhibited spontaneous synaptic input, only $2 \%$ of the cells lacking $\mathrm{Na}^{+}$channels showed detectable synaptic input (Fig. 5e, significantly different, $P=2 \times 10^{-17}$ ). Thus, the two classes of OPC sense their environment in different ways. 


\section{The two OPC classes respond differently to ischaemia}

The cells expressing voltage-gated $\mathrm{Na}^{+}$channels exhibited significantly more glutamate $(P=$ $0.014)$ and NMDA $(P=0.004)$ evoked current than cells lacking $\mathrm{Na}^{+}$current (Fig. $\left.5 f\right)$. This larger glutamate receptor mediated response, and the presence of synaptic input, in $\mathrm{Na}^{+}$ channel expressing cells might have clinical implications when glutamate is released in the white matter in conditions of energy deprivation such as stroke, ischaemia following spinal cord injury, and hypoxia/ischaemia contributing to periventricular leukomalacia6,26,27, so we compared the responses of the two classes of OPC to simulated ischaemia (Fig. 6a, b).

Ischaemia evoked a slowly developing inward current in both cell classes, but with three notable differences: in cells with voltage-gated $\mathrm{Na}^{+}$channels the current was significantly larger, had a noisy component generated by a high frequency of spontaneous synaptic currents (which was absent in cells lacking $\mathrm{Na}^{+}$channels), and showed a larger suppression by glutamate receptor blockers (Fig. 6c). TTX had no obvious inhibitory effect on the development of a high synaptic current rate in ischaemia (Fig. 6b, $n=4$ ), as is also the case for hippocampal neurons 28 , suggesting that ischaemia-evoked spontaneous synaptic release is not action potential driven but may reflect a rise of $\left[\mathrm{Ca}^{2+}\right]_{\mathrm{i}}$ in axons when ATP levels fall. Furthermore when TTX was applied during the plateau of the ischaemia-evoked current it had no effect (the ischaemia-evoked current was reduced by $2.7 \pm 2.7 \%$ in 3 cells, $P=0.42$ ), consistent with ischaemic glutamate release being action potential independent, via spontaneous vesicular release and reversal of uptake carriers29. Spontaneous vesicular release of both excitatory and inhibitory transmitter was strongly increased by ischaemia (Fig. 6d).

To test whether the larger glutamate-mediated current evoked by ischaemia in $\mathrm{Na}^{+}$channel expressing cells had a deleterious effect, we exposed P7 cerebellar slices to ischaemia for 1 hour in the presence of propidium iodide to label dead cells, and then fixed the slices and labelled them with antibodies to NG2 and to $\mathrm{Na}^{+}$channels (Fig. 6e). Ischaemia dramatically increased the death of $\mathrm{Na}^{+}$channel expressing cells (35\% killed, $P=3.1 \times 10^{-6}$ compared to the $4 \%$ dead under non-ischaemic conditions: Fig. $6 f)$, but did not significantly increase the death of cells lacking $\mathrm{Na}^{+}$channels ( $2 \%$ killed, $P=0.8$ ). The more than 15 -fold difference in the percentage of the two cell types killed by ischaemia was highly significant $(P=$ $\left.1.5 \times 10^{-5}\right)$. Consistent with the greater glutamate-mediated current in $\mathrm{Na}^{+}$channel expressing cells contributing to the ischaemic vulnerability of these cells, when the slices were made ischaemic in the presence of glutamate receptor blockers ( $25 \mu \mathrm{M}$ NBQX, $50 \mu \mathrm{M}$ D-AP5, 50 $\mu \mathrm{M}$ MK-801, $100 \mu \mathrm{M}$ 7-chlorokynurenate) the death of $\mathrm{Na}^{+}$channel expressing cells was greatly reduced ( $P=1.6 \times 10^{-11}$ compared to no blockers present: Fig. $\left.6 \mathrm{f}\right)$, indeed no significant death of NG2 positive OPCs occurred at all $\left(P=0.3\right.$ for cells expressing $\mathrm{Na}^{+}$ channels compared with no ischaemia, $P=0.5$ for cells lacking $\mathrm{Na}^{+}$channels: Fig. $6 \mathrm{f}$ ).

\section{Discussion}

White matter oligodendrocyte precursor glia have previously been considered as a uniform set of cells which, in situ, express a small amount of voltage-gated $\mathrm{Na}^{+}$current that is insufficient to generate an action potential on depolarization 22,25 (though in culture conditions they can generate a single action potential30). In contrast, our data define two classes of NG2 and Olig2 expressing oligodendrocyte precursor glia with different electrophysiological properties. One type lacks voltage-gated $\mathrm{Na}^{+}$channels completely, while the other type expresses sufficient voltage-gated $\mathrm{Na}^{+}$current to generate trains of action potentials (Figs. 2, 4), and these two classes persist into the adult period after myelination is complete (Fig. $2 \mathrm{f}$ and associated text). Remarkably, only the OPCs that generate action potentials are capable of sensing the neuronal activity in the environment by receiving synaptic input from axons (Fig. 5). 
In addition to the cerebellar data described above, cells with the morphology of OPCs in corpus callosum (of which all 4 cells tested labelled for NG2) also fell into two classes, with $\mathrm{I}_{\mathrm{Na}}(\mathrm{n}=11)$ or without $\mathrm{I}_{\mathrm{Na}}(\mathrm{n}=11)$ (data not shown), suggesting our results are of general relevance to other white matter areas.

Our demonstration that white matter glial cells can generate trains of action potentials challenges current concepts of the distinction between neurons and glia. Conventionally, glial cells do not generate action potentials, and although grey matter oligodendrocyte precursors have been shown to produce a single "immature" action potential in response to current injection, those cells may have been in the process of transforming into neurons 22 .

We envisage two situations in which action potentials will occur in the $\mathrm{I}_{\mathrm{Na}}$ class of OPCs. First, the synaptic input to these cells probably triggers action potentials. The EPSC size at $-40 \mathrm{mV}$ in Fig. 5d implies an EPSC of $\sim 14 \mathrm{pA}$ at a resting potential of $-70 \mathrm{mV}$, which is comparable to the current evoking action potentials in Fig. 4a. Furthermore, the true membrane resistance must be larger than the $1 \mathrm{G} \Omega$ (Fig. 2i) that we record in the presence of shunting by the electrode seal (for microglia31 the true resistance is $\sim 8 \mathrm{G} \Omega$ for a measured value of $2 \mathrm{G} \Omega$ ). This will increase the depolarization produced by EPSCs and promote action potential generation by the synaptic input. Consistent with this, we observed spontaneous action potentials in 1/3 of the cells tested (Fig. 4e). Second, during development a decrease of PDGF-generated tyrosine kinase signalling decreases the cells' membrane $\mathrm{K}^{+}$conductance 32 , which will increase excitability and could lead to action potential generation.

The difference in properties of the two classes of OPC suggests that they serve different functions. Since OPCs have no known output synapse, synaptic input and action potential generation in the $\mathrm{I}_{\mathrm{Na}}$ cells may serve a cell intrinsic role, such as initiating myelination when unmyelinated fibres 24,25 releasing transmitter come close to the OPCs. The inexcitable OPCs do not appear to reflect a later (or earlier) stage of OPC development than the $\mathrm{I}_{\mathrm{Na}}$ cells, since their morphology and expression of NG2 and Olig2 is the same as for the $\mathrm{I}_{\mathrm{Na}}$ cells (Fig. 21), they divide (Fig. 3c,d), and they persist into adulthood after normal oligodendrocyte development is complete (Fig. $2 \mathrm{f}$ and Results text), arguing against them already being committed to becoming mature oligodendrocytes. Conceivably they may carry out a myelination programme independent of transmitter release from axons, whereas the $\mathrm{I}_{\mathrm{Na}}$ cells myelinate axons actively releasing transmitter.

The existence of two classes of OPC has several clinical implications. First, glutamate release induced by energy deprivation in conditions leading to cerebral palsy is believed to preferentially damage OPCs (because they are the main oligodendrocyte lineage cell present at the time the damage occurs)6,26,27,33, and may also damage adult OPCs in ischaemia caused by stroke or spinal cord injury. In neurons a high glutamate receptor density has been suggested to contribute to excitotoxic ischaemia-evoked cell death, by allowing a larger $\mathrm{Ca}^{2+}$ entry when the extracellular glutamate concentration rises34-36. We have shown that the OPCs expressing $\mathrm{Na}^{+}$channels not only generate larger membrane currents when glutamate or NMDA are applied (Fig. 5f), but also generate a larger glutamate-mediated current in ischaemia in part as a result of vesicular release induced by the energy deprivation (Fig. 6a-d). Consistent with this, one hour's ischaemia killed $35 \%$ of $\mathrm{Na}^{+}$channel expressing cells but only $2 \%$ of cells lacking $\mathrm{Na}^{+}$channels, and this selective vulnerability was mediated by glutamate receptors (Fig. 6e,f). This suggests that the class of OPCs expressing $\mathrm{Na}^{+}$channels will be preferentially damaged in conditions leading to cerebral palsy, or in ischaemia caused by stroke or spinal cord injury in the adult, and implies that future therapeutic strategies should focus on these cells. 
Second, it has been suggested 13 that transplantation of OPCs, and subsequent proliferation and differentiation to form mature myelinating oligodendrocytes, could promote remyelination. OPCs may fall into two classes, only one of which can proliferate, both during normal development and in response to demyelination 32,8 , but these two classes do not map onto the two classes of OPC we have characterised since both of these are apparently capable of cell division (Fig. 3c,d). To optimise the therapeutic approach of OPC transplantation, it will be essential to define which of the OPC classes that we report can remyelinate axons.

Finally, some brain tumour cells have oligodendrocyte morphology and so are classed as oligodendrogliomas, but generate action potentials and do not express myelin proteins 37 . They were assumed to be derived from neurons, since glia conventionally do not generate action potentials37. Our data suggest a more parsimonious explanation, i.e. that these tumour cells are derived from the $\mathrm{Na}^{+}$channel expressing class of OPC, reconciling their production of action potentials with their expression of oligodendrocyte lineage markers16,38.

\section{Methods}

Data are from P7 rat cerebellum except where we state that P12 or adult (over 3 months) animals were used.

\section{Immunohistochemistry without electrical recording}

Isolated cerebellum was fixed at $4{ }^{\circ} \mathrm{C}$ overnight in $4 \%$ PFA, cut into 50-70 $\mu \mathrm{m}$ slices, and incubated for $4 \mathrm{hrs}$ in $0.05 \%$ Triton X-100, $10 \%$ goat serum in phosphate-buffered saline at $21^{\circ} \mathrm{C}$, then with primary antibody at $21^{\circ} \mathrm{C}$ overnight with agitation, and then for $4-8 \mathrm{hrs}$ at $21^{\circ} \mathrm{C}$ with secondary antibody. Primary antibodies were: guinea pig NG2 (from W.B. Stallcup, 1:100), rabbit NG2 (Chemicon 1:300), rabbit Olig2 (from D. Rowitch, C.D. Stiles \& J. Alberta, 1:20,000), mouse O4 (Chemicon, 1:50), mouse pan $\mathrm{Na}^{+}$channel (Sigma S8809, 1:50), mouse NeuN (Chemicon 1:400), mouse S100 $\beta$ (Abcam 1:100) and rabbit GalC (1:100). DAPI was used to label nuclei. Secondary antibodies (goat) were: anti-rabbit (Molecular probes, 1:200), anti-mouse IgG (Molecular Probes, 1:200), anti-mouse IgM (Chemicon, 1:200) and anti-guinea pig (Jackson Lab, 1:100). Cell counts were on 10-50 146 $\mu \mathrm{m} \times 146 \mu \mathrm{m} \times 10 \mu \mathrm{m}$ white matter confocal stacks.

\section{Electrophysiology}

Cerebellar slices ( $225 \mu \mathrm{m}$ thick) were made in solution containing $1 \mathrm{mM}$ Na-kynurenate to block glutamate receptors (this was omitted from solutions for experiments). Slices were usually superfused at $33 \pm 1{ }^{\circ} \mathrm{C}$ with bicarbonate-buffered solution, or at $24 \pm 1{ }^{\circ} \mathrm{C}$ with HEPES-buffered solution (for Fig. 5f), containing (mM) $124 \mathrm{NaCl}, 26 \mathrm{NaHCO}_{3}, 1$ $\mathrm{NaH}_{2} \mathrm{PO}_{4}, 2.5 \mathrm{KCl}, 2 \mathrm{MgCl}_{2}, 2.5 \mathrm{CaCl}_{2}, 10$ glucose, bubbled with $95 \% \mathrm{O}_{2} / 5 \% \mathrm{CO}_{2}, \mathrm{pH}$ 7.4; or $144 \mathrm{NaCl}, 2.5 \mathrm{KCl}, 2 \mathrm{MgCl}_{2}, 10$ HEPES, $1 \mathrm{NaH}_{2} \mathrm{PO}_{4}, 2.5 \mathrm{CaCl}_{2}, 10$ glucose, pH set to 7.4 with $\mathrm{NaOH}$, bubbled with $100 \% \mathrm{O}_{2}$. White matter cells (avoiding cerebellar nuclei) were whole-cell clamped with pipettes containing $\mathrm{K}^{+}$-based solution comprising $(\mathrm{mM}) 130$ $\mathrm{KCl}$ or K-gluconate, $4 \mathrm{NaCl}, 0.5 \mathrm{CaCl}_{2}, 10 \mathrm{HEPES}, 10$ EGTA, $4 \mathrm{MgATP}, 0.5 \mathrm{Na}_{2} \mathrm{GTP}$, KLucifer yellow 2, pH set to 7.3 with $\mathrm{KOH}$, or $\mathrm{Cs}^{+}$-based solution comprising (mM) 130 $\mathrm{CsCl}$ or Cs-gluconate, $4 \mathrm{NaCl}, 0.5 \mathrm{CaCl}_{2}, 10 \mathrm{HEPES}, 10 \mathrm{BAPTA}, 4 \mathrm{MgATP}, 0.5 \mathrm{Na}_{2} \mathrm{GTP}$, $\mathrm{K}$-Lucifer yellow 2, pH set to 7.3 with $\mathrm{CsOH}$. Electrode junction potentials were compensated. Peak $\mathrm{I}_{\mathrm{Na}}$ was quantified after subtracting capacity current and an assumed ohmic leak current, scaled from the response to hyperpolarizing pulses. Morphology was assessed from Lucifer filling, by counting cell processes, and drawing a rectangle encompassing all the processes to define the length and width of the field of processes. Post- 
recording labelling was as described19. Series resistance was 8-20 M $\Omega$, before $60 \%$ compensation.

\section{Labelling NG2 cells in living slices}

Cells were incubated in rabbit anti-NG2 antibody (Chemicon 1:100) in external solution for 30-60 mins, washed four times, then incubated in secondary antibody (Molecular Probes $1: 200)$ for $15-30$ mins.

\section{$\mathrm{Na}^{+}$channel labelling}

After labelling with pan $\mathrm{Na}^{+}$channel antibody, cells were defined to express $\mathrm{Na}^{+}$channels if antibody puncta overlapped with the NG2 labelling surrounding an OPC soma or on the proximal processes attached to the soma, i.e. we assume that if a cell expresses $\mathrm{Na}^{+}$channels then there will be some on the soma or proximal processes (rather than the channels being exclusively at the ends of fine processes).

\section{Ischaemia}

To simulate ischaemia we replaced external $\mathrm{O}_{2}$ by $\mathrm{N}_{2}$, and external glucose by $7 \mathrm{mM}$ sucrose, added $2 \mathrm{mM}$ iodoacetate to block glycolysis, and added $25 \mu \mathrm{M}$ antimycin to block oxidative phosphorylation39. For experiments assessing cell death, propidium iodide (37 $\mu \mathrm{M})$ was also in the solution, and for each condition dead cells (defined by bright nuclear propidium labelling: Fig. 3 of Ref. 40) were counted in the white matter of 6-14 confocal stacks $(146 \mu \mathrm{m} \times 146 \mu \mathrm{m} \times 15 \mu \mathrm{m})$ sampled from 4-5 brain slices (225 $\mu \mathrm{m}$ thick). Counting was quasi-blind, with identification of NG2 expressing cells and assessment of $\mathrm{Na}^{+}$channel expression being performed before the propidium iodide channel was turned on, and was repeated by an independent observer. NG2 expressing perivascular cells 15 were excluded. Selective death of $\mathrm{I}_{\mathrm{Na}}$ cells was demonstrated independently in experiments on slices from 3 different animals on different days.

\section{Spontaneous synaptic currents}

A synaptic current was defined to occur if its amplitude was $>3$ times the standard deviation of the current noise and its 10-90\% decay time was longer than its rise time (mean rise time was $2.20 \pm 0.08 \mathrm{msec}$ for 463 inward currents and $2.19 \pm 0.29 \mathrm{msec}$ for 134 outward currents in 4 cells; these relatively long rise times could reflect a larger distance between the transmitter release site and the postsynaptic receptors than is the case for neuron-neuron synapses). Current decays were fitted by one exponential with Strathclyde Electrophysiology Software.

\section{Statistics}

Data are mean \pm s.e.m. $P$ values are from Student's 2-tailed t-tests ${ }_{\text {or }} \mathrm{Chi}^{2}$ tests.

\section{Acknowledgments}

We thank W. Stallcup for NG2 antibody, D. Rowitch, C.D. Stiles \& J. Alberta for Olig2 antibody, and R. Mirsky, K. Jessen, L. Jimenes-Diaz, S. Rakic, C. Eder, P. Mobbs, G. Frugier, A. Silver, A. Gibb \& S. Bolsover for other antibodies, tissue and advice. Supported by the Wellcome Trust, a Wolfson-Royal Society Award to DA and a Royal Society Dorothy Hodgkin Fellowship to RK.

\section{References}

1. Nishiyama A, Lin X-H, Giese N, Heldin C-H, Stallcup WB. Co-localization of NG2 proteoglycan and PDGF alpha receptor on $\mathrm{O} 2 \mathrm{~A}$ progenitor cells in the developing rat brain. J. Neurosci. Res. 1996; 43:299-314. [PubMed: 8714519] 
2. Nishiyama A, Watanabe M, Yang Z, Bu J. Identity, distribution, and development of polydendrocytes: NG2-expressing glial cells. J. Neurocytol. 2002; 31:437-455. [PubMed: 14501215]

3. Stallcup WB. The NG2 proteoglycan: past insights and future prospects. J. Neurocytol. 2002; 31:423-435. [PubMed: 14501214]

4. Horner PJ, Power AE, Kempermann G, Kuhn HG, Palmer TD, Winkler J, Thal LJ, Gage FH. Proliferation and differentiation of progenitor cells throughout the intact adult rat spinal cord. J. Neurosci. 2000; 20:2218-2228. [PubMed: 10704497]

5. Dawson MR, Polito A, Levine JM, Reynolds R. NG2-expressing glial progenitor cells: an abundant and widespread population of cycling cells in the adult rat CNS. Mol. Cell. Neurosci. 2003; 24:476488. [PubMed: 14572468]

6. Volpe JJ. Neurobiology of periventricular leukomalacia in the premature infant. Pediatr. Res. 2001; 50:553-562. [PubMed: 11641446]

7. Levine JM. Increased expression of the NG2 chondroitin-sulfate proteoglycan after brain injury. J. Neurosci. 1994; 14:4716-4730. [PubMed: 8046446]

8. Keirstead HS, Levine JM, Blakemore W. Response of the oligodendrocyte progenitor cell population (defined by NG2 labelling) to demyelination of the adult spinal cord. Glia. 1998; 22:161-170. [PubMed: 9537836]

9. Gensert JM, Goldman JE. Endogenous progenitors remyelinate demyelinated axons in the adult CNS. Neuron. 1997; 19:197-203. [PubMed: 9247275]

10. McTigue DM, Wei P, Stokes BT. Proliferation of NG2-positive cells and altered oligodendrocyte numbers in the contused rat spinal cord. J. Neurosci. 2001; 21:3392-3400. [PubMed: 11331369]

11. Horner PJ, Thallmair M, Gage FH. Defining the NG2-expressing cell of the adult CNS. J. Neurocytol. 2002; 31:469-480. [PubMed: 14501217]

12. Levine JM, Reynolds R, Fawcett JW. The oligodendrocyte precursor cell in health and disease. Trends Neurosci. 2001; 24:39-47. [PubMed: 11163886]

13. Chari DM, Blakemore WF. New insights into remyelination failure in multiple sclerosis: implications for glial cell transplantation. Mult. Scler. 2002; 8:271-277. [PubMed: 12166495]

14. Kondo T, Raff M. Oligodendrocyte precursor cells reprogrammed to become multipotential CNS stem cells. Science. 2000; 289:1754-1757. [PubMed: 10976069]

15. Peppiatt CM, Howarth C, Mobbs P, Attwell D. Bidirectional control of CNS capillary diameter by pericytes. Nature. 2006; 443:700-704. [PubMed: 17036005]

16. Ligon KL, Alberta JA, Kho AT, Weiss J, Kwaan MR, Nutt CL, Louis DN, Stiles CD, Rowitch DH. The oligodendroglial lineage marker Olig2 is universally expressed in diffuse gliomas. J. Neuropathol. Exp. Pathol. 2004; 63:499-509.

17. Ligon KL, Kasari S, Kitada M, Sun T, Arnett HA, Alberta JA, Anderson DJ, Stiles CD, Rowitch DH. Developmental of NG2 neural progenitor cells requires Olig gene function. Proc. Natl. Acad. Sci., U.S.A. 2006; 103:7853-7858. [PubMed: 16682644]

18. Káradóttir R, Cavelier P, Bergersen L, Attwell D. NMDA receptors are expressed in oligodendrocytes and activated in ischaemia. Nature. 2005; 438:1162-1168. [PubMed: 16372011]

19. Káradóttir R, Attwell D. Combining patch-clamping of cells in brain slices with immunocytochemical labelling to define cell type and developmental stage. Nature Protocols. 2006; 1:1977-1986.

20. Dawson MRL, Levine JM, Reynolds R. NG2-expressing cells in the central nervous system: are they oligodendroglial progenitors? J. Neurosci. Res. 2000; 61:471-479. [PubMed: 10956416]

21. Alonso G. NG2 proteoglycan-expressing cells of the adult rat brain: possible involvement in the formation of glial scar astrocytes following stab wound. Glia. 2005; 49:318-338. [PubMed: 15494983]

22. Chittajallu R, Aguirre A, Gallo V. NG2-positive cells in the mouse white and grey matter display distinct physiological properties. J. Physiol. 2004; 561:109-122. [PubMed: 15358811]

23. Dayer AG, Cleaver KM, Abouantoun T, Cameron HA. New GABAergic interneurons in the adult neocortex and striatum are generated from different precursors. J. Cell. Biol. 2005; 168:415-427. [PubMed: 15684031] 
24. Kukley M, Capetillo-Zarate E, Dietrich D. Vesicular release of glutamate from axons in white matter. Nat. Neurosci. 2007; 10:311-320. [PubMed: 17293860]

25. Ziskin JL, Nishiyama A, Rubio M, Fukaya M, Bergles DE. Vesicular release of glutamate from unmyelinated axons in white matter. Nat. Neurosci. 2007; 10:321-330. [PubMed: 17293857]

26. Follett PL, Rosenberg PA, Volpe JJ, Jensen FE. NBQX attenuates excitotoxic injury in developing white matter. J. Neurosci. 2000; 20:9235-9241. [PubMed: 11125001]

27. Káradóttir R, Attwell D. Neurotransmitter receptors in the life and death of oligodendrocytes. Neuroscience. 2007; 145:1426-1438. [PubMed: 17049173]

28. Allen NJ, Attwell D. The effect of simulated ischaemia on spontaneous GABA release in area CA1 of the juvenile rat hippocampus. J. Physiol. 2004; 561:485-498. [PubMed: 15459240]

29. Li S, Mealing GA, Morley P, Stys PK. Novel injury mechanism in anoxia and trauma of spinal cord white matter: glutamate release via reverse $\mathrm{Na}^{+}$-dependent glutamate transport. J Neurosci. 1999; 19:RC16. [PubMed: 10407058]

30. Barres BA, Koroshetz WJ, Swartz KJ, Chun LL, Corey DP. Ion channel expression by white matter glia: the O-2A glial progenitor cell. Neuron. 1990; 4:507-524. [PubMed: 1691005]

31. Newell EW, Schlichter LC. Integration of $\mathrm{K}^{+}$and $\mathrm{Cl}^{-}$currents regulate steady-state and dynamic membrane potentials in cultured rat microglia. J. Physiol. 2005; 567:869-890. [PubMed: 16020460]

32. Chittajallu R, Aguirre AA, Gallo V. Downregulation of platelet-derived growth factor-alpha receptor-mediated tyrosine kinase activity as a cellular mechanism for $\mathrm{K}^{+}$-channel regulation during oligodendrocyte development in situ. J. Neurosci. 2005; 25:8601-8610. [PubMed: 16177027]

33. Back SA, Luo NL, Borenstein NS, Levine JM, Volpe JJ, Kinney HC. Late oligodendrocyte progenitors coincide with the developmental window of vulnerability for human perinatal white matter injury. J. Neurosci. 2001; 21:1302-1312. [PubMed: 11160401]

34. Kawasaki K, Traynelis SF, Dingledine R. Different responses of CA1 and CA3 regions to hypoxia in rat hippocampal slice. J. Neurophysiol. 1990; 63:385-394. [PubMed: 2158521]

35. Vornov JJ, Tasker RC, Coyle JT. Direct observation of the agonist-specific regional vulnerability to glutamate, NMDA, and kainate neurotoxicity in organotypic hippocampal cultures. Exp. Neurol. 1991; 114:11-22. [PubMed: 1717307]

36. Fukuda A, Muramatsu K, Okabe A, Shimano Y, Hida H, Fujimoto I, Nishino H. NMDA receptormediated differential laminar susceptibility to the intracellular $\mathrm{Ca}^{2+}$ accumulation induced by oxygen-glucose deprivation in rat neocortical slices. J. Neurophysiol. 1998; 79:430-438. [PubMed: 9425211]

37. Patt S, Labrakakis C, Bernstein M, Weydt P, Cervos-Navarro J, Nisch G, Kettenmann H. Neuronlike physiological properties of cells from human oligodendroglial tumors. Neuroscience. 1996; 71:601-611. [PubMed: 9053811]

38. Marie Y, Sanson M, Mokhtari K, Leuraud P, Kujas M, Delattre J-Y, Poirier J, Zalc B, Hoang-Xuan K. Olig2 as a specific marker of oligodendroglial tumour cells. Lancet. 2001; 358:298-300. [PubMed: 11498220]

39. Allen NJ, Káradóttir R, Attwell D. A preferential role for glycolysis in preventing the anoxic depolarization of rat hippocampal area CA1 pyramidal cells. J. Neurosci. 2005; 25:848-859. [PubMed: 15673665]

40. Kondo RP, Wang SY, John SA, Weiss JN, Goldhaber JI. Metabolic inhibition activates a nonselective current through connexin hemichannels in isolated ventricular myocytes. J. Mol. Cell Cardiol. 2000; 32:1859-1872. [PubMed: 11013130] 


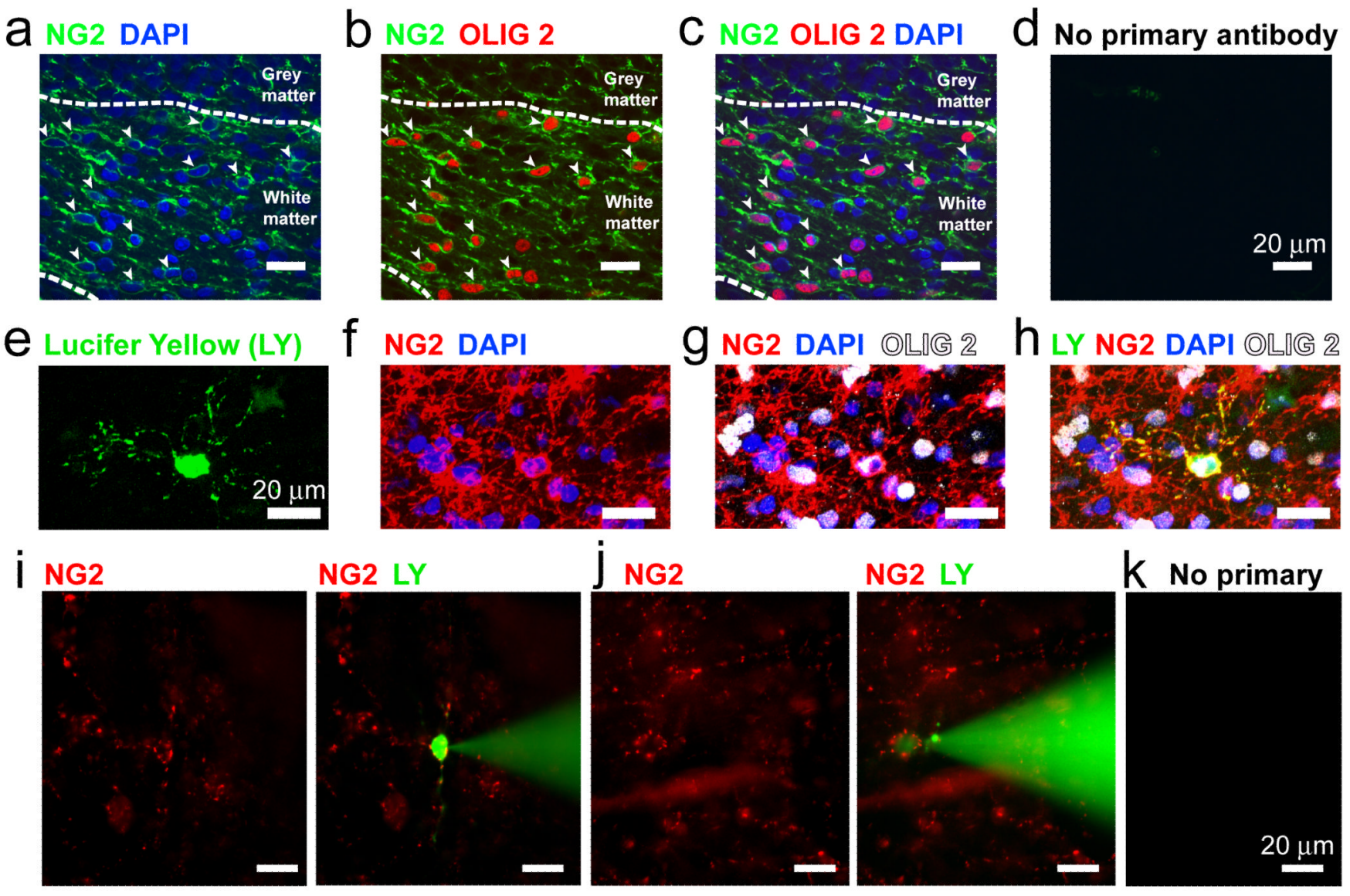

Figure 1. Oligodendrocyte precursor identification

a-d Fixed P7 cerebellar white matter labelled for NG2, Olig 2, and DAPI (stains cell nuclei). Closed arrows show cells labelled for NG2 and Olig2. e-h $\mathrm{I}_{\mathrm{Na}}$ cell filled with Lucifer yellow, labelled post-recording for NG2 and Olig2. i-k Using NG2 antibody in living slices to select cells for patch clamping: $\mathbf{i}$ no $\mathrm{I}_{\mathrm{Na}}$ cell; $\mathbf{j} \mathrm{I}_{\mathrm{Na}}$ cell; $\mathbf{k}$ no labelling without primary antibody. 


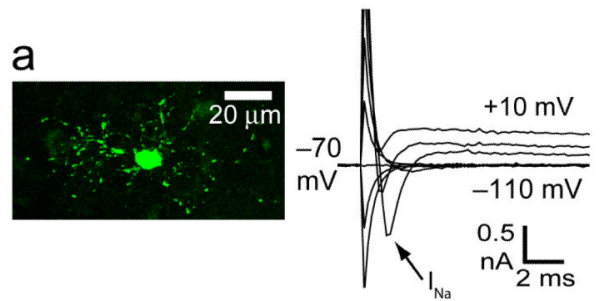

C

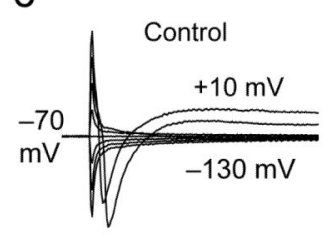

e pan $\mathrm{Na}$

DAPI
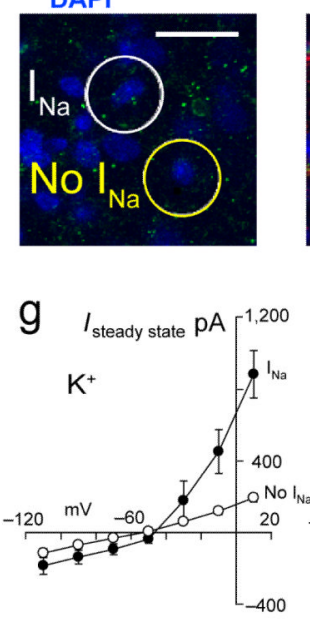

$\mathrm{k}$
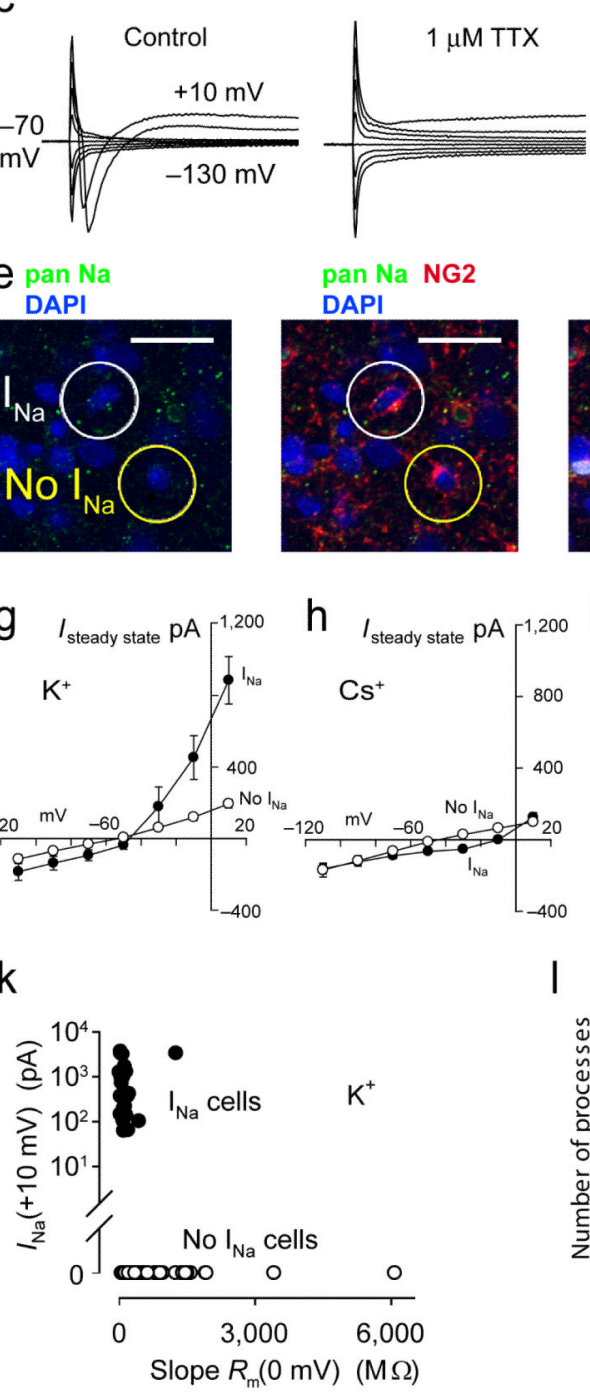

h $I_{\text {steady state }} \mathrm{PA}[1,200$ $\mathrm{b}$

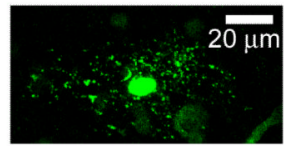

$20 \mu \mathrm{m}$
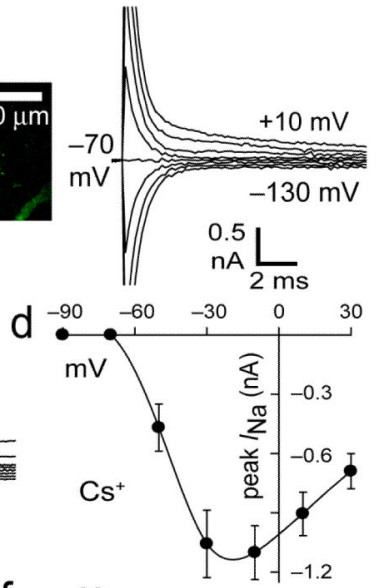

${ }_{\mathrm{nA}}^{0.5} \mathrm{Lm}$
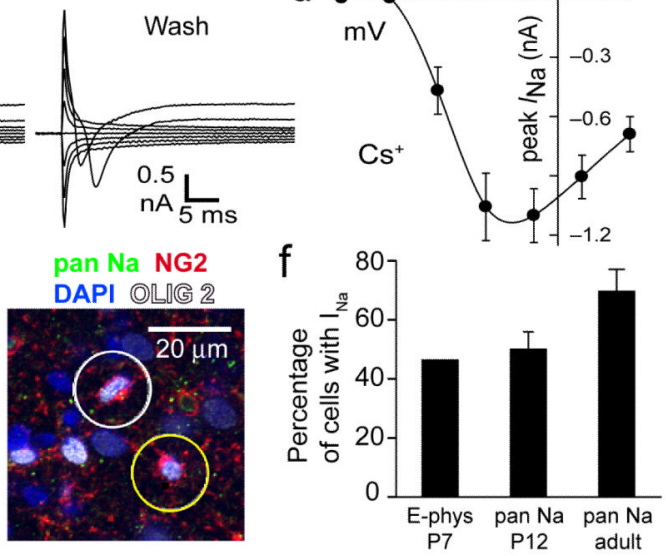
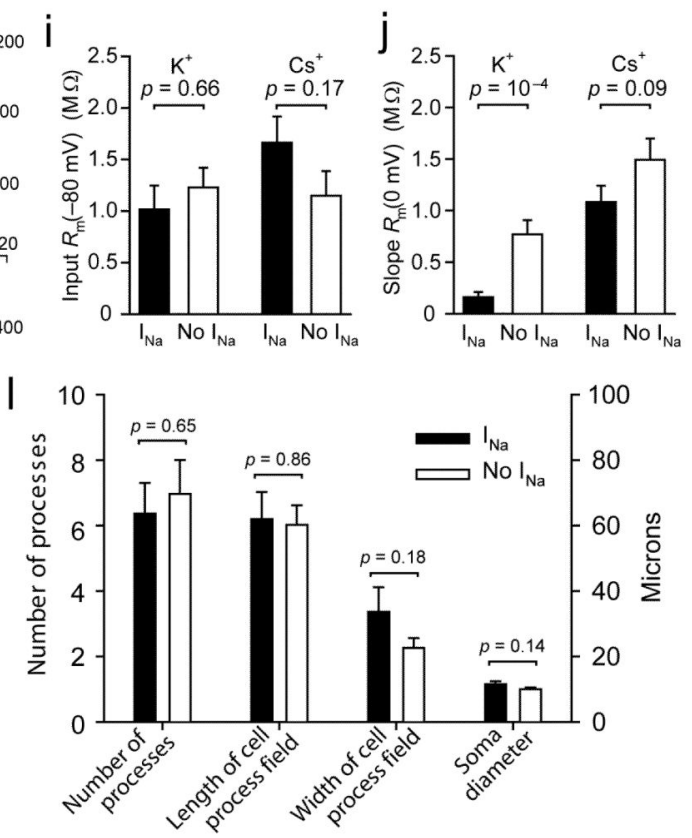

Figure 2. Two classes of oligodendrocyte precursor glia

a P7 NG2 cell filled with Lucifer yellow, showing voltage-gated $\mathrm{Na}^{+}$current $(20 \mathrm{mV}$ steps from $-70 \mathrm{mV}$ ). b As a but cell lacking $\mathrm{I}_{\mathrm{Na}}$. c $1 \mu \mathrm{M}$ TTX blocks $\mathrm{I}_{\mathrm{Na}}$. d Peak $\mathrm{I}_{\mathrm{Na}}(\mathrm{V})( \pm$ s.e.m.) in 76 cells $\left(\mathrm{Cs}^{+}\right.$internal). e Fixed P12 cerebellar white matter labelled for voltage-gated $\mathrm{Na}^{+}$ channels (pan Na; non-NG2 cell labelling is presumably axonal), NG2 and Olig2. Circles show an $\mathrm{I}_{\mathrm{Na}}$ and a no $\mathrm{I}_{\mathrm{Na}}$ cell. $\mathbf{f}$ Percentage of white matter OPCs with $\mathrm{I}_{\mathrm{Na}}$ by electrophysiology at P7, and by pan Na labelling at P12 (out of 101 NG2/Olig2 cells) and in adult (out of $28 \mathrm{NG} 2 / \mathrm{Olig} 2$ cells). $\mathrm{g}$ I-V relation at end of $0.2 \mathrm{sec}$ voltage steps for 25 cells with and 51 cells without $\mathrm{I}_{\mathrm{Na}}\left(\mathrm{K}^{+}\right.$internal, at P7). h As g but Cs ${ }^{+}$internal, 67 cells with and 
55 without $\mathrm{I}_{\mathrm{Na}}$. $\mathbf{i}$ Input resistance at $-80 \mathrm{mV}$. $\mathbf{j}$ Slope resistance at $0 \mathrm{mV}$. $\mathbf{k}$ Peak $\mathrm{I}_{\mathrm{Na}}$ on depolarizing from $-70 \mathrm{mV}$ to $+10 \mathrm{mV}$, versus slope resistance at $0 \mathrm{mV}$ (at P7). $\mathbf{l}$ Morphological parameters in $32 \mathrm{I}_{\mathrm{Na}}$ and 35 no $\mathrm{I}_{\mathrm{Na}}$ cells at $\mathrm{P} 7$. 


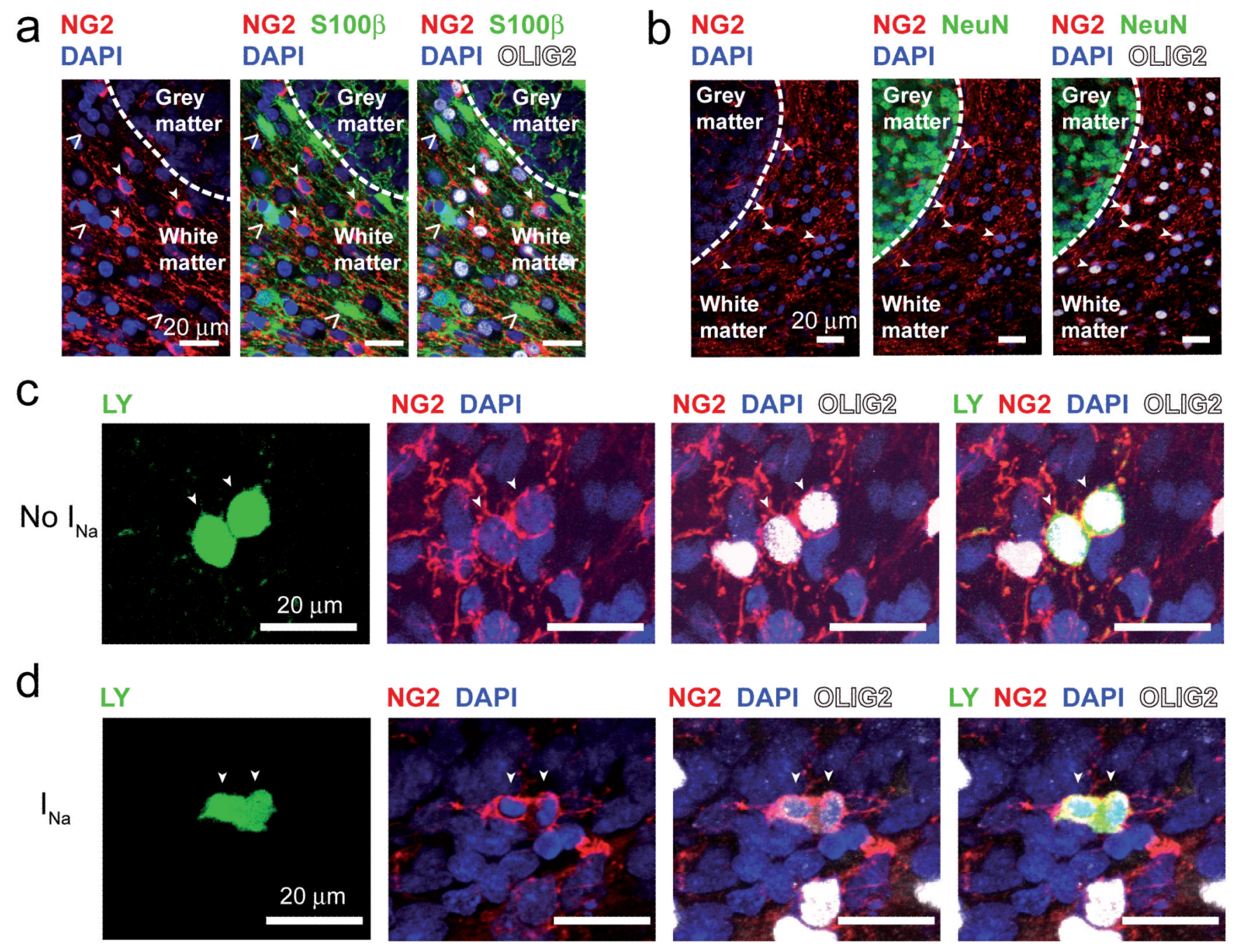

Figure 3. Oligodendrocyte precursors proliferate, but do not label for astrocyte or neuronal markers

a,b Fixed P1 2 tissue labelled for NG2, Olig2, DAPI and S100 $\beta$ (a, open arrows show S100 $\beta$ cells) or NeuN (b). Closed arrows show cells labelled for NG2 and Olig2. c Recorded cell $\left(\mathrm{P} 7\right.$, no $\mathrm{I}_{\mathrm{Na}}$ ) revealed as dividing into two cells by Lucifer yellow fill (arrows), labelled postrecording for NG2, Olig2 and DAPI. d As in c but with $\mathrm{I}_{\mathrm{Na}}$, showing cytoplasmic continuity between the dividing cells and the nuclei drawn apart into each daughter cell. 

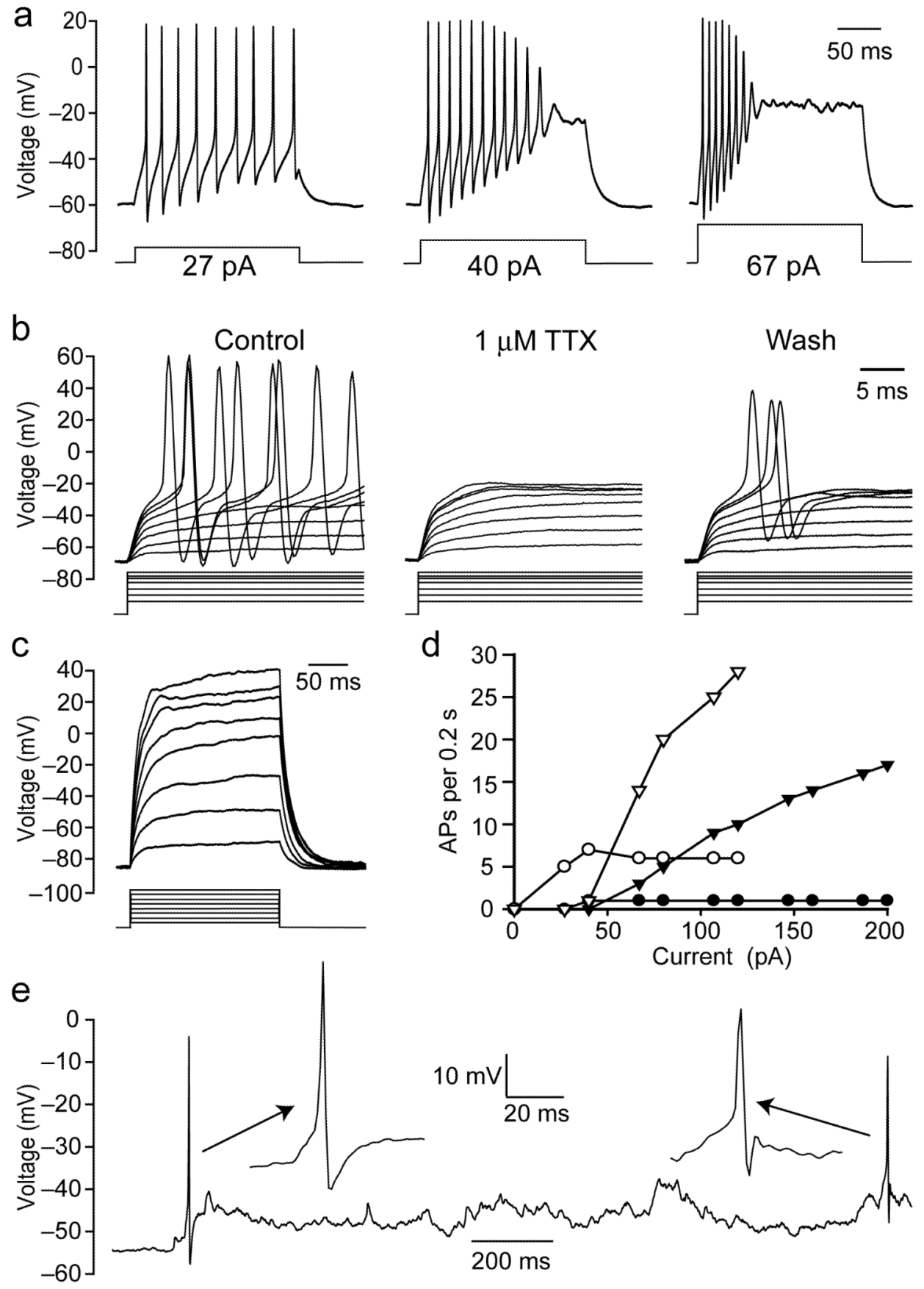

Figure 4. Oligodendrocyte precursor glia with $\mathrm{Na}^{+}$current generate action potentials a Response to current injection of P7 OPC with $\mathrm{I}_{\mathrm{Na}}$. b Action potential suppression by TTX (currents ranged from 48-266 pA). c Lack of action potentials in a cell lacking $\mathrm{I}_{\mathrm{Na}}$ (currents from 40-320 pA). d Number of action potentials/200 msec pulse as a function of injected current, in 4 cells. e Spontaneous action potentials in an $\mathrm{I}_{\mathrm{Na}}$ cell. All $\mathrm{K}^{+}$-gluconate internal. 

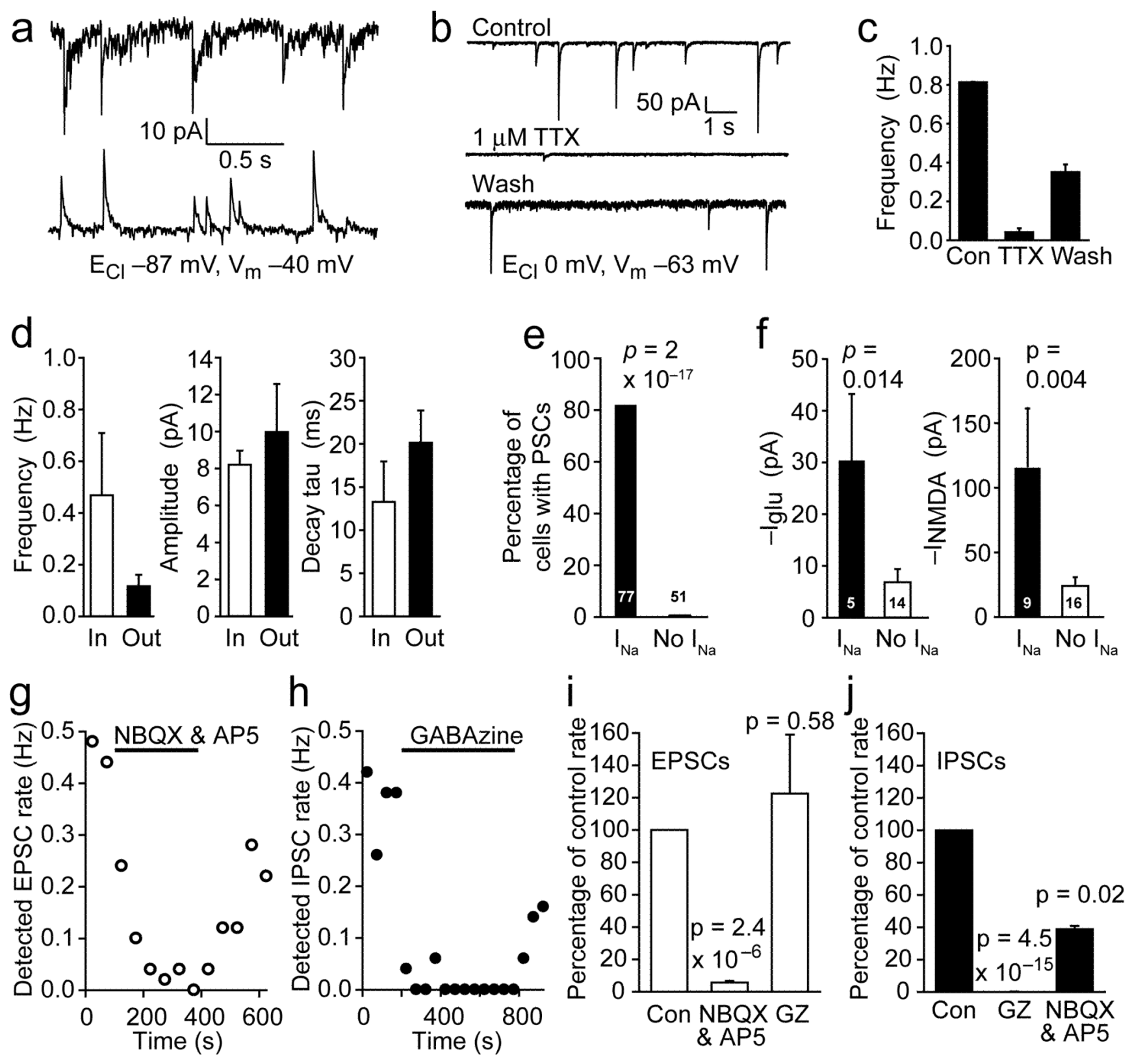

Figure 5. Oligodendrocyte precursor glia with and without $\mathbf{I}_{\mathbf{N a}}$ sense the environment differently a Inward and outward spontaneous postsynaptic currents (PSCs) in two different P7 NG2 cells with $\mathrm{I}_{\mathrm{Na}}$ (the different current noise level in the 2 cells is of no significance). $\mathbf{b} 1 \mu \mathrm{M}$ TTX blocks synaptic currents at $-63 \mathrm{mV}$ (since $\mathrm{E}_{\mathrm{Cl}}=0 \mathrm{mV}$ these currents need not be EPSCs but could be inward IPSCs caused by action potentials evoking the release of GABA from Purkinje cell axons). The increased current noise in the wash trace is of no significance. c TTX data (as in b, \pm s.e.m.) from 3 cells. d Properties of inward and outward synaptic currents at $-40 \mathrm{mV}$ with $\mathrm{E}_{\mathrm{Cl}}=-87 \mathrm{mV}$ in 4 cells. e Proportions of $\mathrm{I}_{\mathrm{Na}}$, and no $\mathrm{I}_{\mathrm{Na}}$, cells showing synaptic currents (cell numbers are on bars). f Response at -63 mV of NG2 cells with and without $\mathrm{I}_{\mathrm{Na}}$ to $100 \mu \mathrm{M}$ glutamate, and $60 \mu \mathrm{M}$ NMDA in $0 \mathrm{mM} \mathrm{Mg}^{2+}$. g-j Pharmacology of synaptic currents at $-40 \mathrm{mV}$. g Frequency of detected EPSCs is greatly reduced by NBQX $(25 \mu \mathrm{M})$ and D-AP5 $(50 \mu \mathrm{M})$. h Frequency of detected IPSCs is greatly 
reduced by GABAzine (GZ, $10 \mu \mathrm{M})$. i Pharmacology of EPSCs ( 4 cells). j Pharmacology of IPSCs ( 6 cells for GZ, 2 cells for NBQX+AP5). Cs-gluconate internal, $\mathrm{E}_{\mathrm{Cl}}-87 \mathrm{mV}$, except b, c \& f using $\mathrm{CsCl}$. 


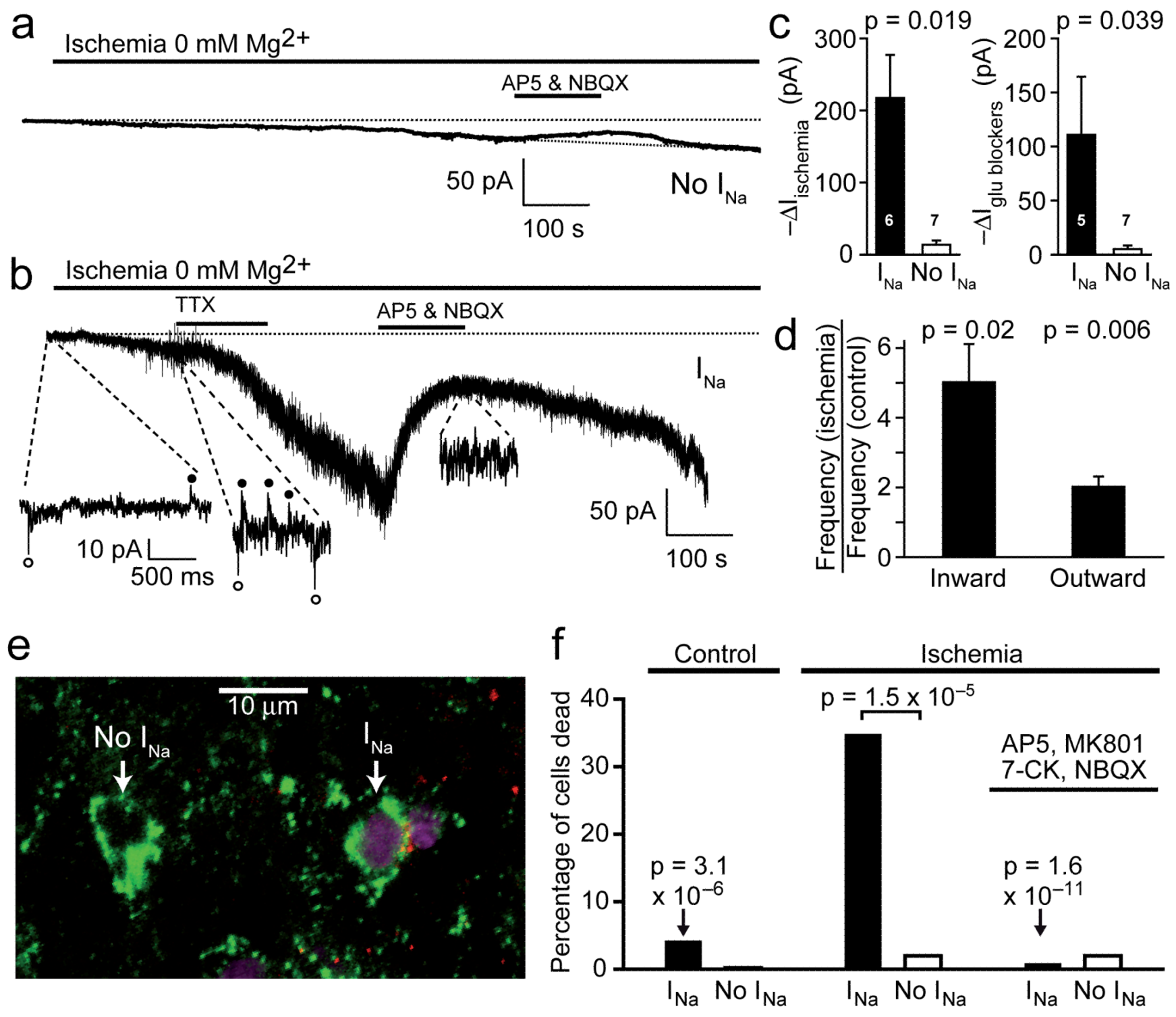

Figure 6. Oligodendrocyte precursor glia with and without $\mathrm{I}_{\mathrm{Na}}$ respond differently to ischaemia a Response of a P7 OPC lacking $\mathrm{I}_{\mathrm{Na}}$ to simulated ischaemia $\left(0 \mathrm{mM} \mathrm{Mg}{ }^{2+}\right.$ enhances detection of NMDA receptor currents, $-40 \mathrm{mV}$ ), and block of glutamate-mediated component of current by $200 \mu \mathrm{M}$ AP5 and $25 \mu \mathrm{M}$ NBQX. b As a, but for a cell with $\mathrm{I}_{\mathrm{Na}}$, showing spontaneous synaptic currents (circles) contribute to the response. The greater noise in the trace for the $\mathrm{I}_{\mathrm{Na}}$ cell reflects the presence of synaptic input which is lacking in the no $\mathrm{I}_{\mathrm{Na}}$ cell, and the presence of a larger number of glutamate-gated channels in the $\mathrm{I}_{\mathrm{Na}}$ cell. c Ischaemia-evoked inward current and current suppressed by glutamate receptor blockers (at 500-800 sec after starting ischaemia, \pm s.e.m.) in $\mathrm{I}_{\mathrm{Na}}$ and no $\mathrm{I}_{\mathrm{Na}}$ cells. Analysing the current inhibition as a percentage of the ischaemia-induced current showed the same difference between the $\mathrm{I}_{\mathrm{Na}}$ and no $\mathrm{I}_{\mathrm{Na}}$ cells: in $\mathrm{I}_{\mathrm{Na}}$ cells the inhibition was $71.5 \pm 9.7 \%$ of the ischaemia-evoked current, while in no $\mathrm{I}_{\mathrm{Na}}$ cells it was $24.0 \pm 15.2 \%$ (significantly different, $P=0.035)$. d Frequency of inward and outward spontaneous synaptic currents at $-40 \mathrm{mV}$ in 4 cells after $1 \mathrm{~min}$ ischaemia (relative to pre-ischaemia). Cs-gluconate internal, $\mathrm{E}_{\mathrm{Cl}}-87 \mathrm{mV}$, in a-d. e Labelling of P7 slice for NG2 (green), $\mathrm{Na}^{+}$channels (red, or yellow/orange where overlapping with NG2) and with propidium iodide (mauve) after 1 hour's ischaemia, 
showing death of an $\mathrm{I}_{\mathrm{Na}}$ cell and no death of a no $\mathrm{I}_{\mathrm{Na}}$ cell. f Percentage of NG2 positive $\mathrm{I}_{\mathrm{Na}}$ cells and no $\mathrm{I}_{\mathrm{Na}}$ cells killed in control conditions (no ischaemia, 103 NG2 expressing cells), after 1 hour's ischaemia (166 cells), or after 1 hour's ischaemia in the presence of $25 \mu \mathrm{M}$ NBQX, $50 \mu \mathrm{M}$ D-AP5, $50 \mu \mathrm{M}$ MK-801 and $100 \mu \mathrm{M}$ 7-chlorokynurenate (7-CK) (173 cells). All $P$ values are for comparison with $\mathrm{I}_{\mathrm{Na}}$ cells in ischaemia without blockers. 